\title{
American Political Science Review Editor's Report for 1998-99
}

\author{
Ada W. Finifter, Editor, American Political Science Review, Michigan State University
}

$T^{\mathrm{h}}$ he number of submissions during 1998-99 was about the same as in the previous three years. We received 536 manuscripts, 393 of them original. The average figure for 1995-99 shows an increase of $11 \%$ as compared to the Powell editorship and $26 \%$ as compared to the Patterson editorship. The trend shown in Table 1 suggests an even heavier workload for the next editor. The selection of a new editor to begin September 1, 2001, is a propitious time to consider a shared or more decentralized editorial structure.

During August 1999, we observed the now-customary "moratorium" on new submissions, which has worked very well. Obviously, it does not decrease overall submissions, but it permits staff to take summer vacations without interfering unduly with efficient processing of new manuscripts. Our experience is that July has become an exceptionally heavy month, and we usually are processing manuscripts that arrive in late July well into August. The moratorium applies only to new manuscripts; the office remains open during August, and we continue to work on revisions, reviews, July submissions, and preparation of the December issue, which goes to press early in September.

\section{Field Representation of Manuscripts Received and Published}

Table 2 shows the distribution of substantive fields for all manuscripts received over the last 15 years, with submissions for each of the previous editorships given as totals and with yearly breakdowns given for my editorship. As explained in previous reports (e.g., Finifter 1997), the coding system for formal theory submissions has changed, and these are now coded according to substantive field whenever possible (e.g., a pa- per about the U.S. Congress that would have been coded as formal theory through 1996 is now coded as American politics). The apparent decline in formal theory manuscripts is thus only an artifact of the coding process. Overall, the distribution is fairly stable over this relatively long period, with perhaps a small proportionate (not numerical) decline in American politics and a small increase in comparative politics.

The distribution of new manuscripts by field and method for the last three years is shown in Table 3. Generally speaking, the distribution is stable, although there may be a slight upward tendency in the number of papers in American and comparative politics that offer both formal analysis and quantitative tests. The numbers are too small to constitute a trend, but my impression is that interest is growing in empirical tests of formal theories; for example, reviewers of formal theory papers increasingly often ask for or applaud such tests. Otherwise, the distribution by field and method seems quite stable over the last three years.

Table 4 shows the breakdown by field for articles published since 1985. There is some variation by year, but the small annual differences do not seem meaningful (since one manuscript represents approximately $2 \%$ of each year's total). Any unusual year-to-year fluctuations generally result from random variation or a particular situation that produces more articles in a certain field. For example, the substantial increase in 1997 in international relations articles was due largely to publication of an exchange consisting of a critique and five responses. As compared to 1996 and 1997 , the representation of American politics increased to its more usual level in 1998; it increased still more in 1999, when two forums involving that topic were published. Based on the general pattern, the diversity of articles published indicates that the Review is an important outlet for most fields of political science.

Manuscripts in all fields of the discipline and using all methods of analysis are welcome at the APSR, and each submission is revicwed by other scholars working in the same area and using similar analytic methods. There is no filtering process to encourage or discourage any type of manuscript. The extent to which articles published in the Review are not totally representative of research in the discipline at large is reflective of a self-selection process by authors. The published articles are quite representative of the manuscripts received.

\section{Turnaround Time}

Prompt processing is a major goal of the editorial office, although this is difficult given the traditional structure of a single editor and the high number of submissions. Manuscripts are generally sent to three revicwers, whose selection is based on research by the APSR interns and advice from the editorial board on each manuscript. In order to speed the process for authors whose papers are unlikely to be accepted, rejections are based on the first two reviews received when both clearly advise against publication. In the case of mixed reviews, decisions often take considerably longer.

Table 5 shows the median amount of time for different stages of the editorial process over the last 15 years. Data for the editorships of Patterson and Powell are summarized from their reports. Data for my editorship are shown for the past year and also for the four-year total. Only manuscripts for which a decision has been reached are included, so the current year's annual data are less stable than the total figures.

"From receipt to referee assignment" reports the median number 


\section{TABLE 1}

\section{Manuscripts Received by APSR}

\begin{tabular}{cccc}
\hline & & \multicolumn{2}{c}{ Number of Submissions } \\
\cline { 3 - 4 } & & Total & Original \\
\hline A. Yearly Totals & $1998-99$ & 536 & 393 \\
& $1997-98$ & 540 & 411 \\
& $1996-97$ & 533 & 491 \\
& $1995-96$ & 495 & \\
& $1994-95$ & 480 & \\
& $1993-94$ & 487 & \\
& $1992-93$ & 479 & \\
B. Editorship Averages & $1991-92$ & 438 & \\
Finifter & $1990-91$ & 428 & \\
Powell & $1989-90$ & 447 & \\
Patterson & $1988-89$ & 391 & \\
& $1987-88$ & 427 & \\
\hline
\end{tabular}

Note: For 1995-99, annual periods range from August 15-August 14. The total column includes revisions; the breakdown between original and total submissions was not provided in previous editorial reports.

Sources: Data for 1991-95, and average for 1986-91, are taken from Powell (1995, Table 1). The average for 1991-95 is calculated from the same source. Individual year data for 1986-87 to 1990-91 are taken from Patterson, Bruce, and Crone (1991, Table 1).

of days for choosing reviewers and mailing a manuscript to them. ${ }^{\prime}$

"From assignment to last review" is the median number of days it takes for reviewers to respond. "From last review to decision" indicates the time the editor takes to make deci- sions and send a letter to the author after the final review used in the decision has arrived (that is, the second of two negative reviews or three reviews if they are mixed or positive). ${ }^{3}$ "From receipt to final decision" is the total number of days in the process for all manuscripts received. (This last figure is not a simple addition of the previous number of days, because it also includes papers that are not sent for external review.)

The number of manuscripts received obviously affects how rapidly they can be processed. The current turnaround time is as good as or better than that of the two previous editors, despite the considerable increase in the number of manuscripts. Some outliers do wait a long time for a decision, either because of unusual reviewer problems or because conflicting reviews require the editor to take additional time to make a decision, which can sometimes involve consultation with members of the editorial board. I regret any long waits, but they are largely due to efforts to give all manuscripts a fair review and to avoid arbitrary decisions. We constantly strive to improve turnaround time.

\section{Acceptance Rates}

\section{Acceptance Rates by Field}

The page count of the APSR is determined by APSA Council action as part of the budgetary process. The Review currently is allowed the same number of pages per volume as was determined when the largesize format was adopted with the 1992 volume. Therefore, as the sub-

TABLE 2

Manuscripts Received by Field, 1985-99

\begin{tabular}{|c|c|c|c|c|c|c|c|}
\hline & $1985-91$ & $1991-95$ & $1995-96^{a}$ & $1995-96^{b}$ & $1996-97^{b}$ & $1997-98^{b}$ & $1998-99^{b}$ \\
\hline American Politics and Public Policy & $41 \%$ & $35 \%$ & $34 \%$ & $38 \%$ & $39 \%$ & $38 \%$ & $38 \%$ \\
\hline Comparative Politics & 17 & 22 & 18 & 23 & 25 & 22 & 24 \\
\hline International Relations & 10 & 12 & 9 & 13 & 13 & 11 & 12 \\
\hline Normative Political Theory & 19 & 21 & 19 & 19 & 16 & 17 & 18 \\
\hline Formal Theory & 13 & 10 & 18 & 5 & 5 & 9 & 6 \\
\hline Methodology & - & - & 2 & 2 & 2 & 3 & 2 \\
\hline Total & $100 \%$ & $100 \%$ & $100 \%$ & $100 \%$ & $100 \%$ & $100 \%$ & $100 \%$ \\
\hline Number of Manuscripts & 426 & 485 & 533 & 533 & 540 & 537 & 536 \\
\hline
\end{tabular}

${ }^{a}$ Allocates formal theory papers in all fields to the formal theory category for consistency with previous editorial reports. Finifter (1997) presents more detailed discussion of field codes.

${ }^{b}$ Allocates formal theory and methodology papers to their substantive field (American Politics, Comparative Politics, or International Relations) whenever possible (based on type of data used in analysis).

Sources: The average for 1985-91 is from Powell (1995, Table 1). The average for 1991-95 is calculated from the same source. 


\begin{tabular}{|c|c|c|c|c|c|c|}
\hline Subfield and Type of Analysis & & -97 & & -98 & & -99 \\
\hline \multicolumn{7}{|l|}{ American Politics } \\
\hline Formal and Quantitative & 10 & $2.56 \%$ & 8 & $1.95 \%$ & 17 & $4.33 \%$ \\
\hline Formal & 8 & 2.05 & 8 & 1.95 & 3 & .76 \\
\hline Interpretive, Conceptual & 9 & 2.30 & 15 & 3.65 & 10 & 2.54 \\
\hline Quantitative & 125 & 31.97 & 121 & 29.44 & 112 & 28.50 \\
\hline Small N & & & 2 & .49 & & 1.25 \\
\hline Subfield Total & 152 & $38.88 \%$ & 154 & $37.47 \%$ & 143 & $36.39 \%$ \\
\hline \multicolumn{7}{|l|}{ Comparative Politics } \\
\hline Formal and Quantitative & 5 & $1.28 \%$ & 9 & $2.19 \%$ & 12 & $3.05 \%$ \\
\hline Formal & 9 & 2.30 & 7 & 1.70 & 7 & 1.78 \\
\hline Interpretive, Conceptual & 19 & 4.86 & 17 & 4.14 & 11 & 2.80 \\
\hline Quantitative & 46 & 11.76 & 50 & 12.17 & 53 & 13.49 \\
\hline Small $N$ & 14 & 3.58 & 4 & .97 & 9 & 2.29 \\
\hline Subfield Total & 93 & $23.78 \%$ & 87 & $21.17 \%$ & 92 & $23.41 \%$ \\
\hline \multicolumn{7}{|l|}{ International Relations } \\
\hline Formal and Quantitative & 3 & $.77 \%$ & 11 & $2.68 \%$ & 7 & $1.78 \%$ \\
\hline Formal & 10 & 2.56 & 6 & 1.46 & 13 & 3.31 \\
\hline Interpretive, Conceptual & 9 & 2.30 & 6 & 1.46 & 8 & 2.04 \\
\hline Quantitative & 22 & 5.63 & 21 & 5.11 & 23 & 5.85 \\
\hline Small $N$ & 1 & .26 & 1 & .24 & & \\
\hline Subfield Total & 45 & $11.52 \%$ & 45 & $10.95 \%$ & 51 & $12.98 \%$ \\
\hline \multicolumn{7}{|l|}{ Normative Theory } \\
\hline Formal & & & 1 & $.24 \%$ & 2 & $.51 \%$ \\
\hline Interpretive, Conceptual & 70 & $17.90 \%$ & 83 & 20.19 & 74 & 18.83 \\
\hline Subfield Total & 70 & $17.90 \%$ & 84 & $20.44 \%$ & 76 & 19.34 \\
\hline \multicolumn{7}{|l|}{ Formal Theory of General } \\
\hline \multicolumn{7}{|l|}{ Political Processes } \\
\hline Formal and Quantitative & & & 2 & $.49 \%$ & 2 & $.51 \%$ \\
\hline Formal & 20 & $5.11 \%$ & 25 & 6.08 & 19 & 4.83 \\
\hline Interpretive, Conceptual & & & 3 & .73 & 2 & .51 \\
\hline Quantitative & & & & & 1 & .25 \\
\hline Subfield Total & 20 & $5.11 \%$ & 30 & $7.30 \%$ & 24 & $6.11 \%$ \\
\hline \multicolumn{7}{|l|}{ Methodology } \\
\hline Formal and Quantitative & 1 & $.26 \%$ & 2 & $.49 \%$ & 1 & $.25 \%$ \\
\hline Formal & & & 1 & .24 & & \\
\hline Interpretive, Conceptual & 5 & 1.28 & 3 & .73 & 2 & .51 \\
\hline Quantitative & 5 & 1.28 & 5 & 1.22 & 4 & 1.04 \\
\hline Subfield Total & 11 & $2.81 \%$ & 11 & $2.68 \%$ & 7 & $1.78 \%$ \\
\hline Total Original Submissions & 391 & $100.00 \%$ & 411 & $100.01 \%$ & 393 & $100.00 \%$ \\
\hline
\end{tabular}

mission number increases, the acceptance rate necessarily declines.

Table 6 presents acceptance rates by field for original manuscripts received in the last four years and decided by early October 1999. These calculations count manuscript "chains," that is, all original manuscripts and their revisions, if any, are counted as one manuscript chain. Considering all original manuscripts received over the last four years, the acceptance rate is $9.2 \%$. The rate is fairly similar across fields except for general formal theory and methodology. In these two areas, the small number of submissions means that acceptance rates can be noticeably affected by a very small number of manuscripts.

\section{Acceptance Rates by Round}

Decision letters on revisions are categorized in the office as "invite" or "permit," depending on the amount of encouragement I give the 
TABLE 4

Articles Published by the APSR by Subfield, 1985-99

\begin{tabular}{|c|c|c|c|c|c|c|c|c|c|}
\hline & $1985-91$ & 1992 & 1993 & 1994 & 1995 & 1996 & 1997 & 1998 & 1999 \\
\hline American Politics and Public Policy & $42 \%$ & $34 \%$ & $39 \%$ & $36 \%$ & $38 \%$ & $30 \%$ & $27 \%$ & $35 \%$ & $43 \%$ \\
\hline Comparative Politics & 16 & 17 & 19 & 23 & 18 & 20 & 20 & 22 & 19 \\
\hline Normative Political Theory & 20 & 24 & 18 & 21 & 20 & 25 & 22 & 17 & 20 \\
\hline International Relations & 10 & 13 & 14 & 9 & 6 & 16 & 25 & 13 & 8 \\
\hline Formal Theory ${ }^{a}$ & 13 & 11 & 11 & 11 & 18 & 9 & 6 & 11 & 8 \\
\hline Methodology & & & & & & & & 2 & 2 \\
\hline Total & $100 \%$ & $99 \%$ & $101 \%$ & $100 \%$ & $100 \%$ & $100 \%$ & $100 \%$ & $100 \%$ & $100 \%$ \\
\hline Number of Manuscripts & 49 & 53 & 57 & 53 & 49 & 44 & 51 & 46 & 49 \\
\hline
\end{tabular}

aFor 1996-99, formal theory and methodology articles that also use empirical data are coded in their substantive subfields (American politics, comparative, or international relations).

author based primarily on my reading of the reviews. For manuscripts with reviews that are marginal but supportive enough to "permit" revision, I always suggest that authors consider carefully whether a further investment of their time in the APSR review process seems worthwhile, in light of their own assessments of the likelihood that they can resolve the issues raised by the re- viewers. Authors are always advised that there are no guarantees on resubmissions, although authors who are invited to revise receive more encouragement to resubmit. ${ }^{4}$

Table 7 shows that the nuances of these decision letters are very clear to authors and that, in the aggregate, authors respond rationally and appropriately. At each stage, recipients of "invite" letters are signifi- cantly more likely to resubmit than are recipients of "permit" letters. It is also interesting that the response patterns by round differ between the two groups. At each further round, those invited to revise are increasingly likely to resubmit, whereas those permitted to revise are less likely to resubmit after the first round. Thus, the likelihood of resubmission by the two groups increas-

\section{TABLE 5}

\section{Elapsed Time in the APSR Review Process by Year of Submission}

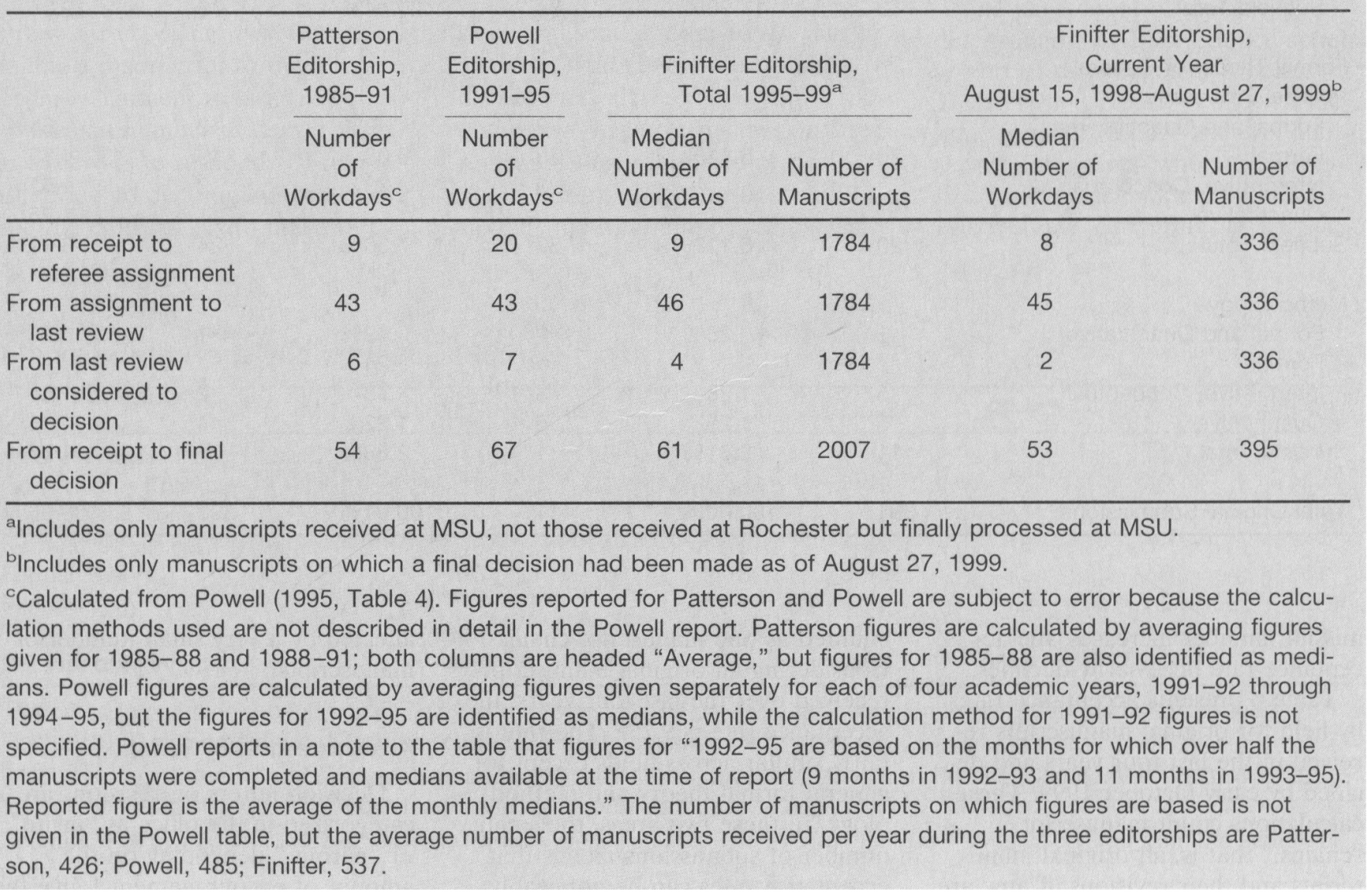


TABLE 6

Acceptance Rates by Field, for Original Manuscripts

Submitted since August 17, 1995 and Decided by

October 8, 1999

\begin{tabular}{lccc}
\hline \multicolumn{1}{c}{ Field } & $\begin{array}{c}\text { Number of Original } \\
\text { Submissions }\end{array}$ & $\begin{array}{c}\text { Number } \\
\text { Accepted }\end{array}$ & $\begin{array}{c}\text { Acceptance } \\
\text { Rate }\end{array}$ \\
\hline American Politics & 601 & 58 & $9.7 \%$ \\
Comparative Politics & 364 & 27 & $7.4 \%$ \\
Normative Theory & 311 & 26 & $8.4 \%$ \\
International Relations & 195 & 21 & $10.8 \%$ \\
Formal Theory & 94 & 14 & $14.9 \%$ \\
Methodology & 46 & 2 & $5.1 \%$ \\
Total & 1604 & 148 & $9.2 \%$ \\
\hline
\end{tabular}

ingly diverges as the rounds

progress. This makes sense: A favorable outcome continues to seem likely for the first group, but the greater caution expressed in letters to the second group leads authors to be more likely to cut their losses after the first try.

Table 8 indicates outcomes on the original and subsequent revision rounds for all manuscripts received during my editorship and decided as of early October 1999. Given the large number of submissions, the small number we can accept, and our rigorous revicw procedures, very few manuscripts are accepted in the first round. Only $2 \%$ have such a swift positive outcome. Almost $40 \%$ of first revisions are rejected when resubmitted, and only $26 \%$ of first revisions are accepted. Nevertheless, of the 184 papers accepted during my editorship, $60 \%$ were accepted in the original or first-revision rounds. Another $30 \%$ were accepted after the second revision, and the remaining $10 \%$ went to a third revision before being accepted.
Second and third revisions are generally undertaken only when specific requirements or analyses are proposed to the authors, either by the reviewers or the editor, and a positive outcome appears likely. Often these revisions respond to requests for authors to include specific technical information. As Table 8 shows, approximately two-thirds of papers that go through two or more revisions are accepted.

Table 9 provides detail on the outcome of the revision process at each stage according to the decision in the previous stage. Invited resubmissions are much more likely to be accepted than are permitted resubmissions. At the same time, the data indicate that the chance of acceptance for a permitted revision is not so low that it makes no sense to try, as long as the author's personal situation allows time for a risky investment. In general, I have created a relatively permissive resubmission environment and am willing to work with authors as long as reviewers suggest reasonable prospects for eventual publication. In this scheme of things, it is the author's responsibility to assess his or her own risk tolerance and resubmit only when a negative decision can be tolerated.

Given the relatively low acceptance rate, the Review does not have a large backlog for publication; in fact, it can be described as a "justin-time" manuscript inventory. As of mid-October 1999, there was still some space in the March 2000 issue.

\section{Book Reviews}

As shown in Table 10, between Scptember 1998 and August 1999 more than 1,800 books were received, or approximately five books a day (including Saturdays and Sundays). ${ }^{5}$ Each is entered into our database and considered for review. Approximately $18 \%$ of the books received (328) have been reviewed or are scheduled for revicw. An average of more than 80 books are reviewed in each issue of the Review. Three formats are used: single-book reviews of around 1,000 words; multiple-book revicws (usually two or three books) between 1,500 and 2,000 words; and review cssays, which range from 5,000 to 10,000 words.

Table 10 also shows the number of books received and the percentages of books reviewed by ficld. The largest category is comparative politics (654), followed by American politics and policy (507), international relations (344), and political theory $(270)$. More than $20 \%$ of the books received in the two smallest categories were reviewed, compared to slightly more than $15 \%$ for the two largest categories.

TABLE 7

Author Decisions to Resubmit by Decision and Round, for All Manuscripts Submitted and Decided between August 17, 1995 and October 8, 1999

\begin{tabular}{|c|c|c|c|c|c|c|}
\hline \multirow[b]{2}{*}{$\begin{array}{c}\text { Resubmitted } \\
\text { to Date? }\end{array}$} & \multicolumn{2}{|c|}{ Original Submission } & \multicolumn{2}{|c|}{ First Revision } & \multicolumn{2}{|c|}{ Second Revision } \\
\hline & $\begin{array}{l}\text { Invite } \\
\text { Revision }\end{array}$ & $\begin{array}{c}\text { Permit } \\
\text { Revision }\end{array}$ & $\begin{array}{l}\text { Invite } \\
\text { Revision }\end{array}$ & $\begin{array}{c}\text { Permit } \\
\text { Revision }\end{array}$ & $\begin{array}{l}\text { Invite } \\
\text { Revision }\end{array}$ & $\begin{array}{l}\text { Permit } \\
\text { Revision }\end{array}$ \\
\hline Yes & $72 \%$ & $49 \%$ & $74 \%$ & $30 \%$ & $92 \%$ & $33 \%$ \\
\hline No & 28 & 51 & 26 & 70 & 8 & 67 \\
\hline Total & $100 \%$ & $100 \%$ & $100 \%$ & $100 \%$ & $100 \%$ & $100 \%$ \\
\hline $\mathrm{N}$ & (209) & $(176)$ & $(68)$ & (33) & (13) & (6) \\
\hline
\end{tabular}




\begin{tabular}{|c|c|c|c|c|c|c|c|c|}
\hline \multirow[b]{2}{*}{ Reject } & \multicolumn{2}{|c|}{ New Submissions } & \multicolumn{2}{|c|}{ First Revision } & \multicolumn{2}{|c|}{ Second Revision } & \multicolumn{2}{|c|}{$\begin{array}{c}\text { Third or Later } \\
\text { Revision }\end{array}$} \\
\hline & $67.5 \%$ & (1083) & $39.2 \%$ & (116) & $16.9 \%$ & $(14)$ & $17.2 \%$ & (5) \\
\hline $\begin{array}{l}\text { Permit Revise and } \\
\text { Resubmit }\end{array}$ & 11.0 & (176) & 11.1 & (33) & 6.0 & (5) & 3.4 & (1) \\
\hline $\begin{array}{l}\text { Invite Revise and } \\
\text { Resubmit }\end{array}$ & 13.0 & (209) & 23.0 & (68) & 9.6 & (8) & 17.2 & (5) \\
\hline Accept & 2.1 & (33) & 26.4 & (78) & 66.3 & (55) & $62.1 \%$ & (18) \\
\hline Other & 6.4 & (103) & .3 & (1) & 1.2 & (1) & & \\
\hline$\%(\mathrm{~N})$ & $100.0 \%$ & (1604) & $100.0 \%$ & (296) & $100.0 \%$ & (83) & $99.9 \%$ & (29) \\
\hline
\end{tabular}

The books reviewed by field for the five most recent issues are given in Table 11. In September 1998, for example, $28 \%$ were in American politics, $26 \%$ in comparative politics, $27 \%$ in political theory, and $20 \%$ in international relations. In other words, there was a rough balance among the fields. Moreover, due to a small backlog of reviews, the fluctuations from issue to issue can be kept relatively small.

The book review section has historically faced two major problems. The first is that resources are barely adequate. The office has three halftime graduate students working under the book review editor. There is barely enough time to open cartons, enter books into the database, decide on which books to review, find potential reviewers, manage corre- spondence (with reviewers, publishers, and authors), send reviews out for copy editing, prepare an issue for publication, and review page proofs (these are checked in-house and are not sent back to reviewers).

The second problem is that there is a major problem in locating reviewers. All authors want their book reviewed, but just about everyone prefers not to write reviews. The professional rewards from a review of one's book in the APSR are great; the professional rewards for writing a review for the APSR are small. The result is that it is not unusual for us to make a half dozen or even a dozen requests before locating a reviewer. This takes a lot of time, so the second problem intensifies the first.

The book review editor has histor- ically heard two major complaints. The first is: Why was my book not reviewed? The most likely candidates for review are books authored or coauthored by political scientists, representing original research, and published by a major university press. The least likely candidates are books not by political scientists, in the form of an edited collection of reprints designed as a textbook, and not published by a university press. These long-standing criteria reflect our aim to review the most important books written in political science, just as the APSR aims to publish the most important articles in political science.

The second complaint is: Why did you choose that idiot who wrote a negative review of my book? The book review interns use several

\section{TABLE 9}

\section{Outcomes for Revisions by Decision at Prior Stage for Manuscripts Submitted since August 17, 1995 and Decided by October 8, 1999}

\begin{tabular}{|c|c|c|c|c|c|c|}
\hline \multirow[b]{3}{*}{$\begin{array}{l}\text { Decision on Subsequent } \\
\text { Submission }\end{array}$} & \multicolumn{6}{|c|}{ Decision on } \\
\hline & \multicolumn{2}{|c|}{ Original Submission } & \multicolumn{2}{|c|}{ First Revision } & \multicolumn{2}{|c|}{$\begin{array}{c}\text { Second or Later } \\
\text { Revision }\end{array}$} \\
\hline & $\begin{array}{l}\text { Invite } \\
\text { Revision }\end{array}$ & $\begin{array}{l}\text { Permit } \\
\text { Revision }\end{array}$ & $\begin{array}{l}\text { Invite } \\
\text { Revision }\end{array}$ & $\begin{array}{l}\text { Permit } \\
\text { Revision }\end{array}$ & $\begin{array}{l}\text { Invite } \\
\text { Revision }\end{array}$ & $\begin{array}{l}\text { Permit } \\
\text { Revision }\end{array}$ \\
\hline \multicolumn{7}{|l|}{ Accept or Conditionally } \\
\hline Accept & $40 \%$ & $15 \%$ & $70 \%$ & $40 \%$ & $67 \%$ & $50 \%$ \\
\hline Invite Revise and Resubmit & 29 & 20 & 8 & 10 & 25 & - \\
\hline Permit Revise and Resubmit & 9 & 14 & 4 & 20 & 0 & - \\
\hline Reject & 22 & 51 & 18 & 30 & 8 & 50 \\
\hline Total & $100 \%$ & $100 \%$ & $100 \%$ & $100 \%$ & $100 \%$ & $100 \%$ \\
\hline $\mathrm{N}$ resubmitted to date & 150 & 86 & 50 & 10 & 12 & 2 \\
\hline
\end{tabular}


databases to generate a set of potential reviewers for the book review editor, along with lists of their most recent publications in the relevant field. All potential reviewers must have published at least three articles or books in the field. If potential reviewers turn us down, we ask them for other recommendations. They usually offer several alternatives, and we again check recent publications. In addition to ensuring reviewer qualifications, we provide guidelines about conflicts of interest and appropriate criticism that all reviewers must follow.

Obviously, the first problem is related to the first complaint: With more resources, perhaps even a separate journal for book reviews, we could review more books. Obviously, the sccond problem is related to the second complaint: Although we think the people invited to review books are generally very well qualified, if cveryone in political science who wrote a Great Book was also willing to write a Great Book Review, what a wonderful world it would be.

\section{Planning for the Future}

In order to gauge satisfaction with Association activities and services, APSA staff recently undertook a mail survey of current and former members; results were reported to the Council at its meeting in April 1999 (APSA 1999b). Unfortunately, the survey had a very low response rate $(\mathrm{N}=103$, a response rate of $10 \%$ for former members, and $\mathrm{N}=$ 250 , a response rate of $25 \%$ for current members). The figures are probably too low to allow valid generalizations, but the survey has nevertheless been used to assess member attitudes toward APSA activities.

Responses to the APSR were mixed in this survey. Among current members, $47 \%$ reported being "satisfied" or "very satisfied" with $A P S R$, while $43 \%$ were "dissatisfied" or "very dissatisfied." Among lapsed members, $51 \%$ were dissatisfied with APSR and $39 \%$ were satisfied (Table 5.2 in the report).

On the bright side for $A P S R$, of 42 association activities asked about in the questionnaire, the Review had
TABLE 10

Books Received, 1997-99, and Books Reviewed, 1998-99

\begin{tabular}{|c|c|c|c|c|}
\hline \multirow[b]{2}{*}{ Field } & \multicolumn{2}{|c|}{ Books Received } & \multicolumn{2}{|c|}{$\begin{array}{c}\text { Books Reviewed or } \\
\text { Scheduled } \\
\text { for Review (of 1998- } \\
99 \text { arrivals) }\end{array}$} \\
\hline & $\begin{array}{l}\text { Sept. 1997- } \\
\text { Aug. } 1998\end{array}$ & $\begin{array}{l}\text { Sept. 1998- } \\
\text { Aug. } 1999\end{array}$ & $\mathrm{~N}$ & $\%$ Across \\
\hline $\begin{array}{l}\text { American Politics and } \\
\text { Public Policy }\end{array}$ & 507 & 500 & 76 & $15.2 \%$ \\
\hline Comparative Politics & 654 & 575 & 91 & $15.8 \%$ \\
\hline Political Theory & 270 & 289 & 67 & $23.1 \%$ \\
\hline International Relations & 344 & 471 & 94 & $20.0 \%$ \\
\hline Total & 1775 & 1835 & 328 & $17.9 \%$ \\
\hline
\end{tabular}

the twelfth highest proportion of "satisfied" or "very satisfied" responses among current members, scoring higher on this measure of satisfaction than the equity of the submission and acceptance process for papers at the Annual Meeting, the APSA awards program for papers, books, and articles, APSA's research grants program, and several other highly visible association activities. $^{6} A P S R$ had the tenth highest proportion of "satisfied" or "very satisfied" responses among former members (Table 5.2 in the report).

Comments written on their questionnaires by members and former members indicated a desire for the APSR to be more representative of research in the discipline, less quantitative and technical, and more rel- evant to their teaching needs (Appendices $\mathrm{A}$ and $\mathrm{B}$ in the report). Some comments about APSR contents, however, indicated little familiarity with what has been published in recent years. Readers who want to see their kind of research appear in the APSR are urged to submit come and will be reviewed in a fair and impartial manner.

This annual report has conmented on the scarcity of space in the APSR for both articles and book reviews. Since the last change in the size of the journal, which took effect with the 1992 volume, the number of regular APSA members has increased by $26 \%$, Annual Meeting registrations have grown by $33 \%$, the Association's operating budget manuscripts for review. All are wel-

\section{TABLE 11}

Books Reviewed by Issue and Field, September 1998-September 1999

\begin{tabular}{ccccc}
\hline Issue & American & Comparative & Theory & $\begin{array}{c}\text { International } \\
\text { Relations }\end{array}$ \\
\hline September 1998 & $28 \%$ & 26 & 27 & 20 \\
December 1998 & $(25)$ & $(23)$ & $(24)$ & $(18)$ \\
March 1999 & $17 \%$ & 35 & 21 & 27 \\
& $(11)$ & $(23)$ & $(14)$ & $(18)$ \\
June 1999 & $27 \%$ & 34 & 17 & 22 \\
September 1999 & $(16)$ & $(20)$ & $(10)$ & $(13)$ \\
& $29 \%$ & 18 & 20 & 33 \\
& $(22)$ & $(14)$ & $(15)$ & $(25)$ \\
& $17 \%$ & 23 & 27 & 33 \\
& $(17)$ & $(23)$ & $(26)$ & $(32)$ \\
\hline
\end{tabular}

Note: Ns include books reviewed in review essays and both multiple- and single-book reviews. Percentages across; rows sum to approximately $100 \%$ due to rounding. 
income has increased by $42 \%$, and operating budget expenditures have risen by $46 \%$. During the last four years, the period of my editorship, membership has increased by $21 \%$, Annual Mecting registrations have grown 19\%, the operating budget income of the Association has increased by $15 \%$, and the operating budget expenditures of the Association have risen $24 \%$, while APSR expenditures have increased by $0.45 \%$, and its budget has declined by $0.63 \% .^{7}$ While funding for the editorial and book review offices of the Review has grown to cover increased postage and other operating expenses including staff salaries and editors' honoraria, the total expenditures for APSR have remained constant due largely to lower printing costs. The result is that association resources devoted to the APSR have declined relative to other association activities. In FY97, APSR's total budget of $\$ 355,953$ (including all printing, mailing, and editorial operations) represented $12 \%$ of the Association's operating budget; for FY2000, the budget of $\$ 353,700$ represents $10 \%$ of the Association's operating budget (APSA 1996, 1999a).

As I reported to the Council at its meeting on September 1, 1999, the publication program of the association is far too small, in my judgment, to accommodate its large and diverse membership. Certainly, the APSR cannot accommodate all of the demands for publication space that are placed on it. I recommended that consideration be given to (1) creating more space for articles, either through an expanded APSR or the creation of other publication vehicles, (2) creating a separate book review journal, (3) developing an expanded editorial structure to deal with the very large workload and diverse types of manuscripts submitted to the Review, and (4) beginning simultaneous print and electronic publication of the Review, as is being undertaken by other political science journals, including AJPS, JOP, and Political Analysis. Any of these activities would require funding not presently available. The question for the membership is the desirability and relative priority of these kinds of ventures as compared to the large number of other worthwhile activities supported by the Association.

As announced on the APSA homepage, the Association has initiated a strategic planning program for the future, with initial recommendations to be made by an elevenmember committee. This is an appropriate committee to hear the views of the membership on publication issues. (See www.apsanet.org/ new/planning for more details.)

I note that it is 689 days, 20 hours, 29 minutes, and 40 seconds (but who's counting?) until the end of my second term as editor of the APSR. The search for the new editor has begun, and the following scholars are serving on the search committee: Peter Gourevitch, University of California, San Diego, chair; Robert Jervis, Columbia University; Gary King, Harvard University; Arlene Saxonhouse, University of Michigan; and Katherine Tate, University of California, Irvine.

\section{APSR Editorial Staff}

The APSR editorial office has a professional staff of one full-time assistant to the editor, Melody Scofield, and one part-time director of manuscript production, Harriett Posner. We also have two part-time independent contractors: copyeditor Elizabeth Johnston and data-

processing consultant Paul Wolberg.

The editorial office could not operate without the APSR interns. Interns read all new submissions and their in-house research on other scholars working in the area of each manuscript assists the editorial board and editor in the process of reviewer selection. During 1998-99, APSR interns Jamie Carson, Chuck Finocchiaro, Erik Herron, Ben Kleinerman, Michelle Kuenzi, Andrew Padon, Jeff Reno, Lisa Shoichet, Mark Souva, and Shane Szalai provided invaluable assistance to the APSR editor, and Book Review Editor Mark Lichbach was assisted by William Aviles, Kenneth Fernandez, and Stacey Searl-Chapin.
The peer-review process could not operate without the advice of our reviewers, all of whom are listed in the December issue of the Review. During 1998-99, we again used almost 1,000 different scholars as reviewers.

Each of these individuals has contributed in different ways to the quality of the APSR, the success of the editorial and book review operations, and the review service we provide to those who submit manuscripts to the Review.

\section{Feedback and Additional Information}

Comments on my report or on editorial procedures of the APSR are always welcome. Readers will also find additional information, including past annual reports of the editor and the editor's notes published in individual issues, at our web site (www.ssc.msu.edu/ apsr).

The APSR web site also includes the table of contents of each issue since March 1996, abstracts and lists of tables and figures for published articles, some supplementary information and analyses listed as "available from author" in the printed articles, a list of forthcoming articles, a comprehensive index of all articles and book reviews published since March 1996, biographical and other information about the editorial board and staff, information about our review procedures, the names of scholars who reviewed for us in each volume year, and "Instructions to Contributors" (also reprinted in the front of each issue) and "Information and Instructions for Authors," which includes formatting and policy information. We have no animation, frames, or fancy graphics, but we hope the site is increasingly useful as we add information.

For comments or questions, please contact us by email at APSR@ssc.msu.edu or by regular mail at APSR, Department of Political Science, Michigan State University, East Lansing, MI 48824-1032. 


\section{Notes}

1. More detailed discussion of turnaround time categories, complications in calculating acceptance rates, and other issues discussed in this report can be found in Finifter (1997).

2. Our reminder procedures and the factors affecting reviewer turnaround time are discussed in Finifter (1996, 763-64).

3. Powell used the same procedure, but I am not certain how his figures took that into account. I cannot report on the Patterson procedures.

\section{References}

American Political Science Association. 1996 "Statement of Income and Expense, July 1, 1995-June 30, 1996, with Revised Budget for FY1997." Distributed to members of the Council for their meeting of August 28,1996 .

- 1999 a. "APSA Summary of Revenue and Expense, FY99 Final vs. FY00 Revised Budget." Distributed to members of the Council for their meeting of September 1, 1999

—. 1999b. "How Are We Doing? Assessments of APSA Programs by Members and Former Members," Typescript. Dis-
4. A more detailed discussion of decision letters can be found in Finifter (1998).

5. This section of the report was written by $A P S R$ Book Review Editor Mark Lichbach.

6. However, the APSR also had higher dissatisfaction scores (and many fewer neutral/no opinion responses) than these other activities. The Review clearly had the most bimodal response pattern of any Association service. Indeed, the modal re-

tributed to members of the Council for their meeting of April 17, 1999.

Finifter, Ada W. 1996. "Report of the Managing Editor of the American Political Science Review, 1995-96." PS: Political Science and Politics 29(4): 758-68.

- 1997. "Report of the Editor of the American Political Science Review, 1996-97." PS: Political Science and Politics 30(4): 783-91.

- 1998. "The 1997-98 Sail on the Flagship American Political Science Review." PS: Political Science and Politics 31(4): 897905. sponse for most other services is neutral/no opinion. In sharp contrast, PS: Political Science and Politics garners a very large majority of "satisfied" and "very satisfied" responses.

7. Changes in APSA membership, meeting registration, and operating budget figures are calculated from yearly data in Rudder (1999, tables 1, 2, and 5). Changes in budget figures for $A P S R$ are calculated from budgetary data in APSA (1996) and APSA (1999a).
Patterson, Samuel C., John M. Bruce, and Martha Ellis Crone. 1991. "The Impact of the American Political Science Revicw." PS: Political Science and Politics 24(4): 765-74.

Powell, G. Bingham Jr. 1995. "Report of the Managing Editor of the American Political Science Review, August 30, 1995."

PS: Political Science and Politics 28(4): 764-69.

Rudder, Catherine E. 1999. "Executive Director's Report." PSOnline < http:/www. apsanet.org/PS/sept $99 /$ rudder.cfm $>$. Accessed October 11, 1999. 